\title{
Az orvosi pszichológia fejlődése hazánkban: szemléleti keretek, határterületek és alkalmazások
}

\author{
Kállai János dr. ${ }^{1}$ - Barabás Katalin dr. ${ }^{2}$ - Túry Ferenc dr. ${ }^{3}$ \\ Csabai Márta dr. ${ }^{4}$. Molnár Péter $\mathrm{dr} .^{5}$
}

\begin{abstract}
${ }^{1}$ Pécsi Tudományegyetem, Általános Orvostudományi Kar, Magatartástudományi Intézet, Pécs ${ }^{2}$ Szegedi Tudományegyetem, Általános Orvostudományi Kar, Magatartástudományi Intézet, Szeged ${ }^{3}$ Semmelweis Egyetem, Általános Orvostudományi Kar, Magatartástudományi Intézet, Budapest

${ }^{4}$ Szegedi Tudományegyetem, Bölcsészettudományi Kar, Pszichológiai Intézet, Szeged

${ }^{5}$ Debreceni Egyetem, Népegészségügyi Kar, Magatartástudományi Intézet, Debrecen
\end{abstract}

\begin{abstract}
A tanulmány az orvosi pszichológia több évtizedes hazai fejlődésének főbb állomásait, fontosabb fogalmait és alkalmazási területeit mutatja be. A kognitív, valamint az affektív idegtudomány és a fejlődéslélektan modern ismereteinek segítségével felvázolja az orvos és a beteg közt alakuló kötődés és bizalom kettős, evolúciós és kulturális eredetét, a diagnózis és a terápia eredményességét meghatározó tényezóket, valamint az empátia lényegét. Bemutatjuk, hogy a pszichoszomatikus orvoslás napjainkra a mindennapi ellátás részévé vált, tudományosan igazolt eredményeinek felhasználása immár a hatékony gyógyítás alappillére. Az orvosi pszichológia és a magatartástudományok integrált oktatása már az egyetemi évek során ennek a szemléletnek a meghonosítására törekszik. Hangsúlyozza továbbá, hogy a beteg test hátráltatja a lelki funkciók kiteljesedését, a lelki betegség pedig testi betegségek komoly kockázati tényezője. Az egészségpszichológiai gondolkodásmód térhódításának példáján érzékeltetjük, hogy a sikeres egészségügyi ellátás az egészség megőrzésében, az egészségmagatartás fejlesztésében érdekelt, autonóm, önmagukért felelősséget vállaló, tájékozott, megfelelő döntések meghozatalában elkötelezett személyeket és a segítségükre lévő, hasonló képességekkel rendelkező gyógyító személyzetet feltételez.
\end{abstract}

Orv Hetil. 2018; 159(36): 1455-1464.

Kulcsszavak: alkalmazott egészségpszichológia, betegközpontúság, hivatásalakítás, kulturális kompetencia, orvosi pszichológia, pszichoszomatika

\section{The medical psychology in Hungary: way of thinking, frame of references and applications}

The present study aims at overviewing the different stages of the education of medical psychology in Hungary. In the perspective of the achievements of cognitive and affective neuroscience as well as developmental psychology, we intend to define the roots of doctor-patient relationship, certain determining factors of diagnosis forming and therapy efficiency as well as the essential components of empathy. We attest to the fact that the current psychosomatic medicine with its evidence-based achievements is a valid component and constitutive pillar of everyday medical care. The integrated university level instruction of medical psychology and behavioral sciences aims at consolidating this perspective. We also emphasize that the ill body hinders adequate psychological functioning and mental disorders provide risk factors concerning somatic illnesses. Through spreading health psychology perspective, we support the concept that in everyday medical care, health protection and the development of health conscious behavior relies on responsible, informed and committed decision-making patients as well as on similarly educated extended medical care teams.

Keywords: applied health psychology, cultural competency, medical psychology, patient-centered thinking, psychosomatics, vocational training

Kállai J, Barabás K, Túry F, Csabai M, Molnár P. [The medical psychology in Hungary: way of thinking, frame of references and applications]. Orv Hetil. 2018; 159(36): 1455-1464.

(Beérkezett: 2018. február 27.; elfogadva: 2018. május 3.)

Semmelweis Ignác születésének 200. évfordulója évében a Szerkesztőség felkérésére készített tanulmány. 


\section{Rövidítések}

$\mathrm{IPO}=$ interprofesszionális oktatás; TBZ = társadalmi beilleszkedési zavarok

\section{Előzmények}

A múlt század hetvenes éveiben végzett, társadalmi beilleszkedési zavarokkal kapcsolatos (Társadalmi beilleszkedési zavarok komplex elemzése, TBZ) kutatási program - sokakat megdöbbentő - eredményei hazánkban is rámutattak a betegségek kialakulásában szerepet játszó szociológiai, kulturális antropológiai és pszichológiai ismereteink hiányosságaira [1]. Napjainkra a társas értékekhez való viszony megváltozott: a kölcsönös bizalom, a demokratikus elvekre épülő problémamegoldási módok egyre fontosabb szerepet nyertek a szorongással, depresszióval küszködőknek, az alkohol és a drog rabságában élóknek, továbbá a testi fájdalmaktól szenvedó betegeknek az ellátásában. A magyar lelkiállapotot vizsgáló újabb tanulmányok feltárták, hogy a reménytelenség, a krónikus stressz, a bizonytalan élethelyzet, a gyógyítási folyamat résztvevői közti együttmúködés hiányosságai többnyire lélektani és társadalmi okokra vezethetók vissza [2]. A felmérések szerint a diagnózis és a kezelési terv elkészítése során a társas kapcsolatok rendellenességeinek kóroki szerepe gyakran elkerüli a terapeuták figyelmét, következésképpen a kórfolyamatot fenntartó patológia egy része kezelés nélkül marad. Az ellátás eredményességét csökkentő, a biopszichoszociális etiológiát figyelmen kívül hagyó gondolkodásmód még napjainkban is tetten érhető [3]. Az 1980-as évek során, a magyar egészség- és mentálhigiénés kultúra évszázados hagyományaira alapozva, lehetôvé vált a testi és a lelki betegségek kölcsönhatásainak részletesebb elemzése, a beteg személyes döntéseinek - együttmúködést és terápiahúséget biztosító - figyelembevétele, továbbá újabb kezelési módok adaptálása. A korábbi évekhez képest a betegellátásban a társadalmi elvárásokhoz való alkalmazkodás nehézségei mellett az egyének, a csoportok és szervezetek fejlődése, a személyes hatékonyság erôsítése, a döntési folyamatokban való részvétel, a történésekkel kapcsolatos átláthatóság, a megbízható információkon alapuló véleménynyilvánítás a figyelem előterébe került. Ezek a szempontok, a személyiségi jogok védelmén keresztül, markáns igényként jelentek meg, színezve a betegeknek az önrendelkezéshez és a gyógyításhoz, valamint a gyógyítókhoz való viszonyát. A személyes kapcsolatok erejét, az egészséges önbizalmat és a kiscsoport-tagok szükségleteinek fontosságát hangsúlyozó toleráns és plurális gondolkodás, a szimmetrikus kapcsolati viszonyok hangsúlyozásával kiegészülve, az egészségügy területén is jelentôs változásokat eredményezett.
Az 1900-as évek elején Magyarország Európában élen járt a lélektani ismeretek egészségügyi alkalmazásában. ${ }^{1}$ Ennek ellenére az 1980-90-es évektől napjainkig a biomedikális és a biopszichoszociális ellátási modell nem fejlődött párhuzamosan. Az orvosi pszichológia egyetemi oktatása és gyakorlati alkalmazásának fejlődése sem volt zökkenőmentes. A kötelező, elektív és fakultatív tárgyak rendszerében az Országos Magatartástudományi Napokon végzett közös szervezőmunka eredményeként megszilárdult a tantárgyak tanrendi struktúrája, egyértelmúvé vált az orvosi pszichológiához köthetố curriculum felépítése és üzenete. Az orvosi pszichológia a nemzetközi gyakorlatnak megfelelően magában foglalja az általános és személyiséglélektani, a betegségcsoportokra lebontott pszichoszomatikával kapcsolatos, magatartásorvoslási és egészségpszichológiai ismereteket, többek között a primer, szekunder és tercier prevenció alapjait. Gyakorlati és elméleti szempontból egyaránt elkerüli a pszichopatológiai fogalomkészletet, mivel elsősorban a beteg és az orvos kapcsolatával és a betegnek a saját betegségére adott adaptív vagy inadaptív nézeteivel foglalkozik. Elsősorban krónikus betegek kezelésében vagy súlyos betegségek maradványtüneteinek elhárításában, a pszichés adaptáció megkönnyítésében játszik alapvető szerepet. Ezzel segíti elő a betegség szomatikus, pszichés és szociális terheivel való küzdelem eredményességét, a komplikációk megelőzését. A hallgatók, a kórházi és klinikai ellátásban dolgozók által is méltányolt tartalma szerint az orvosi pszichológia gyakorlatának érvényesítésében nem az volt a fó kérdés, hogy a gyakorló orvos a nagyobb eredményesség és betegelégedettség elérése érdekében mit tegyen másként, hanem az, hogy nagyobb

Bálint Mihály (1896-1970) pszichoanalitikus és belgyógyász szakorvos Budapesten praktizált, késóbb Angliában, a Tavistock Klinika orvosaként egy Európá ban és Amerikában a mai napig egyaránt nagy népszerüséget élvező, esetismertetésre épülő orvos-beteg kapcsolatfejlesztő csoportmódszert dolgozott ki. A nemzetközi porondon „The doctor, his patient and the illness” (Az orvos, betege és a betegség) című könyve mindmáig a kérdés legnépszerúbb szakmai útmutatója. Ferenczi Sándor (1873-1933) orvos, pszichoanalitikus, a világ első orvosegyetemi pszichoanalitikusi tanszékének megalapítója, Sigmund Freud közvetlen munkatársa, a pszichoanalízis nemzetközileg elismert úttörője és pszichoterápiás alapjainak módszertani fejlesztője volt. Tevékenysége kiemelkedő hatást gyakorolt a magyar és a nemzetközi, irodalmi és kulturális élet fejlődésére. Selye János (1907-1989) fiziológiai kutatásai derítettek fényt a fizikai és a lélektani stresszek szervi betegségeket okozó hatásaira. Ỏ mutatott rá arra, hogy a személy viselkedése, a stresszel kapcsolatos tehetetlensége, a megoldási módozatok hiánya kimeríti a szervezet fiziológiai védekezőkapacitását, ami a testi és a lelki homeosztázist egyaránt veszélyezteti. Alexander Ferenc (Franz Alexander; 1891-1964) orvos, Magyarországon az elmebetegségek biokémiai mechanizmusaival foglalkozott, miközben a pszichoanalízisben is jártasságot szerzett. Továbbá részletesen elemezte a gyomor-bél rendszerre gyakorolt stresszeket, valamint a lélektani konfliktustípusok és a gyomor-bél, a cardiovascularis és a pulmonalis rendszerek múködési zavarainak kölcsönhatásait. Chicagóban megalapította az első pszichoszomatikai intézetet, melynek iskolateremtő ereje nemcsak az Egyesült Államokban, de világszerte hosszú időre meghatározta a pszichoszomatikus orvoslás gyakorlatát. Kopp Mária (1942-2012) orvos, pszichológus, elődei méltó folytatójaként a testi és lelki kölcsönhatások elismert professzora, oktatói, terápiás és szervező tevékenységével a hazai magatartás-orvoslás, a pszichoterápiás, a magatartás- és viselkedéskutatás irányvonalának meghatározó személyisége volt. A magyar lakosság szisztematikus szociológiai és pszichológiai felmérése, az országos egészségállapotról adott diagnózisai az egészségügyi ellátás szervezésének megbízható kiindulópontjai még napjainkban is 
odafigyeléssel, a pszichológiai ismereteinek bővítésén keresztül, munkatársként milyen módon vonja be a beteget a gyógyítás folyamatába. A képzés a gyógyítási tevékenység fejlesztésére és a tapasztalt folyamatok megértésére összpontosított [4]. A biopszichoszociális gondolkodásmód megerősödése a különböző pszichoterápiás módszerek elterjedésére is jelentős hatást gyakorolt. Az 1980-as évektől kezdve a terapeuták részéről - az egészségügyi ellátás széles spektrumában - jelentős igény mutatkozott a pszichoszomatikus ellátás, a klinikai pszichológia és az egészségpszichológia gyakorlati tevékenysége iránt $[5,6]$. A klinikai szemlélet és gyakorlat változásait sajnos nem követte az egészségügyi szolgáltatások megfelelő finanszírozása és minőségfejlesztése. Következésképpen a páciensek fokozódó igényeinek kiszolgálását ezen a területen is részben a magánorvosi ellátás kénytelen magára vállalni. A betegek részéról megmutatkozó biopszichoszociális gyógyítás iránti törekvések azonban elsősorban a krónikus betegek ellátásában, valamint a reprodukciós medicina, a rehabilitációs és palliatív kezelések, a betegségek prevenciója területén nagy szakmai és betegelégedetlenséget kiváltva jelzik, hogy kielégítetlen igények halmozódtak fel az ellátás számos területén.

A napjainkban kiteljesedő tudományos diszciplínákban az integrációelvű, rendszerszemléletű gondolkodás, a személyre szabott, megbízható evidenciákon alapuló ellátás egyre dominánsabbá válik. Ennek a szemléletnek a legfontosabb hordozóeleme a szakterületek közti kapcsolat, az interdiszciplináris érdeklődés erősödése. Az 1980-90-es évek egyetemi központjaiban, Budapesten, Debrecenben, Pécsett és Szegeden megalakuló pszichológiai tanszékek, az egészségügyi területeken dolgozó szakemberek graduális, valamint posztgraduális képzésében részt vállaló orvosi pszichológiai csoportok, majd magatartás-tudományi intézetek létrejötte ennek a fejlődésnek az eredménye. Tevékenységük során a gyógyítás biológiai, pszichológiai, szociális, valamint spirituális törvényszerüségeinek - az egészségügyi dolgozók viselkedését rejtetten vagy szabályokba foglaltan irányító jelenségeknek - a gyakorlati bemutatásával és ezek kutatásával foglalkoztak $[3,7]$. Mindemellett ezek az intézetek immár a betegellátás részeseivé is váltak a gyógyító-megelőző munka különböző területein. Napjainkra az egyes betegcsoportok motivációit és gyógyító-beteg kapcsolati jellegzetességeit elemző kulturális antropológiai, pszichológiai, valamint kommunikációs tudományok az orvoslás elméletének és gyakorlatának nélkülözhetetlen részévé váltak. A gyógyító kapcsolatot a gyógyító szempontjából szabályozó orvosi etika, mind annak csoportszintjeivel foglalkozó orvosi szociológia és az alakuló szociális idegtudományok ismeretrendszere a betegellátás progresszív elemei. Pozitív hozadékként a pszichoszomatikus ellátás egészségügyi jelenléte is felértékelődött. A betegek kórházi és klinikai ellátásában orvos, pszichológus és szociológus között a partneri viszony fokozatosan megerősödött. Az orvostudomány a pszichológiában és a pszichoszomatikus orvoslásban kiváló európai érdemeket szerzett magyar elődökkel büszkélkedhet, akik a test és a lélek kapcsolatát kölcsönhatásban álló, dinamikus folyamatnak tekintették. Hirdették: $\mathrm{Ha}$ a test beteg, a lélek is veszélyben van, ha a lélek beteg, a test is kiszolgáltatott. Az ezen a területen szerzett érdemek a kognitív, majd az affektív idegtudományok eredményeivel kiegészülve új lendületet adtak az elgépiesedő betegellátásnak. A laboratóriumi leletek és a rutinvizsgálatok eredményei mellett a beteg érzései, a betegségéről kialakult gondolatai, az életvitelét meghatározó attitűdjei, motivációi, a betegségről való tudása a betegellátás szerves elemeivé fejlődtek [8]. A kezdeti nehézségek után az orvos magatartása, attitűdje, személyes hatása, kapcsolatkészsége az orvosi identitást megalapozó tudásként, a graduális képzés és a praxis meghatározó részévé vált. A gyakorlatban egyre inkább meghonosodik a betegközpontú gondolkodás, mely szerint a betegség kezelése helyett a beteg ember kezelését kell a gyógyítás fókuszába állítani. Figyelemmel kell kísérni a beteg kockázati tényezőit, maladaptív problémamegoldási módjait, társas és perszonális erőforrásait, a munkájából vagy a szociális helyzetéből adódó akut és krónikus stresszhatásokat is.

\section{Az ember kapcsolatigényének/kötődésének természete és az empátia}

Evolúciós folyamatok eredményeképpen a csecsemő többé-kevésbé fejlett kompetenciarendszerrel jön a világra, és gondozói segítségével aktívan alkalmazkodik a szülők által megteremtett környezethez. Az alkalmazkodás feltétele a megfelelő direkt és indirekt kommunikációs csatornáinak nyitottsága. A kapcsolat harmóniáját és a következményes biztonságérzetet a gesztus, a szemkontaktus, a hangszín, a mimika és a szóbeli közlés tartalmának koherenciája biztosítja. Az érzelmi egymásra hangolódás fiziológiai, gondolati és érzelmi szinkrón jelenségekben mutatkozik meg. Az ember hajlamos szándékot, érzést, vélekedést tulajdonítani a partnerének. Az empátiás kapcsolatban annál nagyobb a valószínüsége annak, hogy a tulajdonítás megfelel a valóságnak, minél mélyebb és bizalmasabb a két fél közti kapcsolat. Az empátia három kardinális eleme, a másik személyben zajló mentális folyamatok (célok, motivációk) megértése, az általa átélt érzések átélése, valamint a felfogott és átélt események konkrét tettekbe fordítása (segítségnyújtás, részvétnyilvánítás, egyes gondolatok visszatükrözése vagy az átértelmezés szándéka) képezi a professzionális gyógyító tevékenység alapját. A képzett segítő mesterien bánik mindhárom elemmel. Képes külön is kezelni az összetevőket, a hangsúlyt mindig a beavatkozás hatékonyságára helyezve [9]. Az empátiás hiányállapotok a korai és a későbbi felnőttkapcsolatokat egyaránt befolyásolják. Módosítják a kognitív (acetilkolin) és az emocionális (dopamin, szerotonin) szabályozás neurotranszmitterrendszereit és azok kapcsolatát, melyek kommunikációs zavarokban és a pszichoszomatikus betegségek iránti vulnerabilitás növekedésében is meg- 
mutatkoznak [10-12]. Az orvos-beteg kapcsolat érzelmi és kognitív tartalma tehát részben a fiziológiai és szociális fejlődés tekintetében szorosan összekapcsolódó korai fejlődési időszakokra vezethető vissza, mind a betegben, mind orvosában/segítőjében. A beteg bizonytalansága, ismerethiánya, félelmei, fájdalmai olyan emberhez irányítják őt, aki képes bizonytalanságát enyhíteni. A megfelelő szakértő jelenlétét megnyugtatóan veszi tudomásul, és az esetek többségében kész a bizalomteljes, empátiás közeg befogadására.

A felnőtt ember az orvos-beteg kapcsolatnak nem passzív résztvevője. A segítő partner felkutatásának sikeressége, a diagnózis megállapítása, a kimenetel megtervezése, az együttmúködés módja összetett egyeztetési folyamat eredménye. A beteg hordozza, átéli, ismeri betegségének tüneteit és kontextusát, mondhatni, szakértője a betegségének. Az orvos pedig tudása, szakmai tapasztalatai birtokában, hasonló esetek ismerete okán, szintén szakértőnek tartja magát. Ez így is van rendjén, de ebben az esetben a két szakértőnek a megfelelő eredmény elérése érdekében kölcsönös felelösségen alapuló döntésekre kell jutnia. A gyógyítás kulcsmozzanata tehát az egymás iránti bizalmon, a különböző beavatkozási szintek figyelembevételével kialakított közös cél eléréséért küzdő felek kapcsolatán múlik (1. ábra).

Az orvosi praxis oldaláról választ kell találnunk arra a kérdésre, hogy az orvos és a beteg között kialakított professzionális kapcsolat milyen módon játszik szerepet a betegségek progressziójában, a betegségekre való fogékonyságban és a terápia kimenetelében. Az alábbiakban tudományos evidenciákon nyugvó válaszokat bemutatva kiemeljük, hogy az ember fiziológiai, biológiai felépítése nem monolit egység, kizárólag társas közegében értelmezhető.

A XX. század egyik legjelentősebb hatású idegtudományi eredménye a tükörneuronok felfedezése. Ismeretükben lehetóvé vált az orvosi praxis egyik hatékony személyes készsége, az empátia természetének részletesebb megértése. Humán és általában emlős egyedekben is jól múködő szociális idegrendszeri modulról, mondhatni, „harmadik szemről” van szó, mely nemcsak a látványt „veszi fel" és tárolja a memóriában, de a látott kép szereplői által elvégzett tettek motoros megfelelőit, sőt a tevékenykedók szándékait - ha akarjuk, ha nem - automatikusan rögzíti. A látvány alapján mintegy „olvassuk” a másik személy szándékait, majd „el is játsszuk” magunkban a látott cselekedeteket. A megfigyelt mozgás és érintés vizuális képe tehát mozgási és érintési érzeteket kelt a megfigyelőben is. Ennek következményeként gondolatot, vágyat, igényt, szándékot tulajdonítunk annak a személynek, aki valamilyen okból figyelmünk előterébe került [13-15]. A szándékok felismerése során szükségszerüen hipotézisekkel élünk, és csak a meggyőző kiegészítő információk gyưjtését, vagyis kérdezést, rápillantást, kapcsolatindítást követően juthatunk döntő következtetés birtokába. További kérdés: mit kezdünk

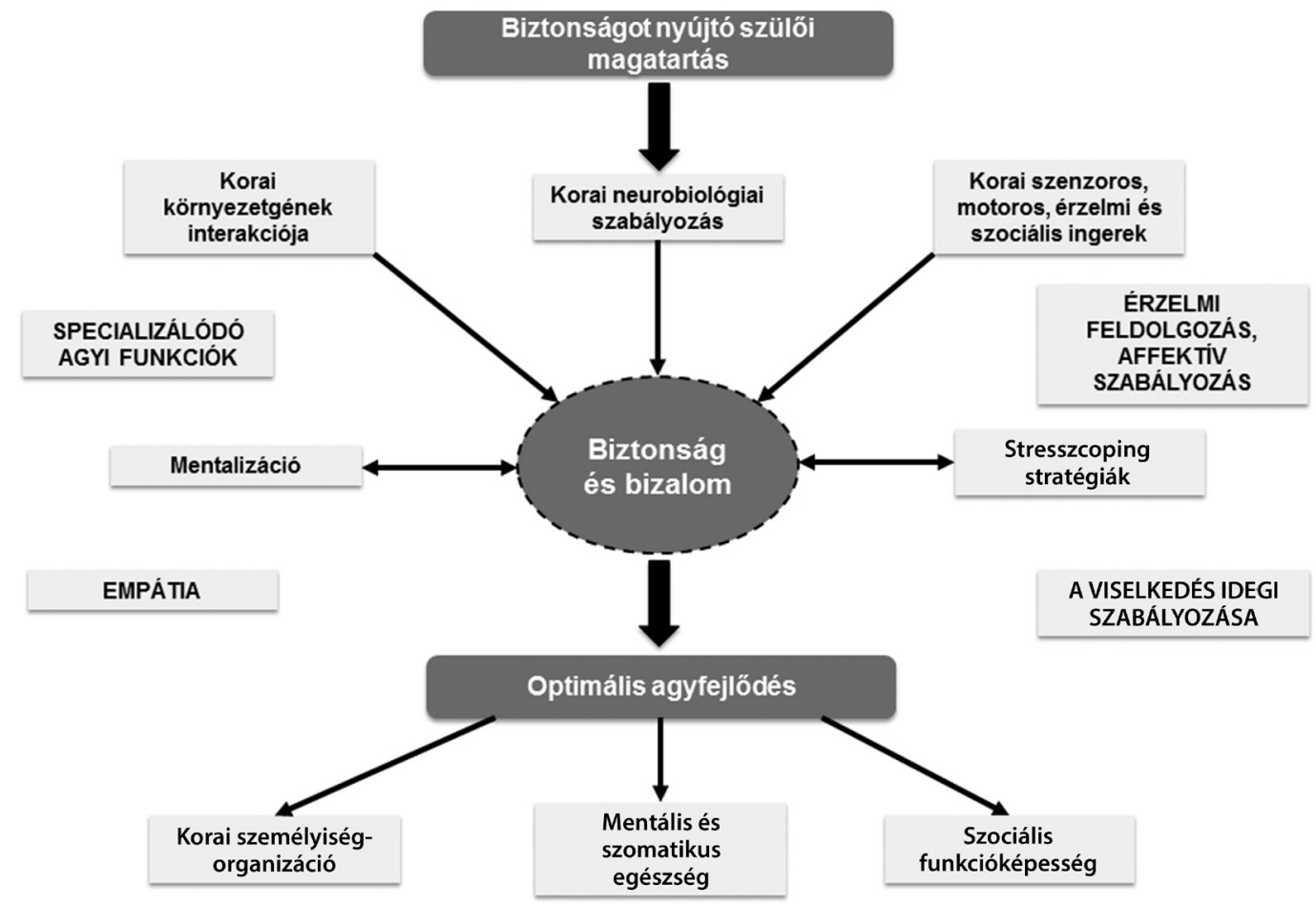

1. ábra $\quad$ Az orvos-beteg kapcsolatot megalapozó empátia kiindulópontja a kölcsönös bizalom, mely részben a csecsemókori kompetenciákra adott szociális reakciók jellegén, emocionális töltésén alapul. A szülói gondoskodáson túl azonban felnőttkorban is fejleszthető. A páciensek viselkedésének motivációi és problémamegoldási módjainak megválasztása, az érzelmi feldolgozásban központi szerepet betöltő mentalizációs (értelemkeresési, szándéktulajdonítási) tevékenységen múlik. Az empátiában a kognitív tevékenység és a fiziológiai reakció egymásba kapcsolódva, elválaszthatatlan egységben van jelen. A biztonságérzés, a partnerre vonatkozó tudás közvetlenül befolyásolja a szervezet homeosztázisát, és a stresszhatásokkal kapcsolatos vulnerabilitást 
ezzel az automatikus, az esetek többségében nem tudatosuló, rendelkezésünkre álló képességgel a mindennapi gyakorlatban, személyes kapcsolatainkban és professzionális munkánk során? Hagyhatjuk a tudattalan homályába veszni, de nyitottak is maradhatunk a multimodális információkat közvetítő „harmadik szem” által kínált üzenetekre. Az empátiás képességból adódik, hogy egyik embert a másiktól a saját bőrfelülete nem választja el, mert fiziológiai, motoros, haptikus és különböző szervi rendszerekkel kapcsolatos aktivitásaik szinkronizált tevékenységet mutatnak. A gyermekét szeretetteljesen megérintő anya testében a szociális ingerek feldolgozását nagymértékben elősegítő oxitocinszint megemelkedik, és hasonló emelkedés mutatkozik az érintést fogadó gyermeke szervezetében is. A hormonszint-emelkedés a kölcsönös szeretet mértékével korrelál, nő a szemkontaktus és a kölcsönös érintésszám [16, 17]. Az érintésnek az agyi ingerületátvivő anyagok mennyiségére gyakorolt hatása felnőttek, valamint orvos és beteg közötti kapcsolat során is hasonló módon zajlik. Az emberek tehát kölcsönös hormonális reakcióikon keresztül kapcsolódnak egymáshoz. A segítségre váró betegek nyitottak az ilyen fiziológiai változásokra, ami nemcsak az orvos által adott gyógyszerekre, de az általa nyújtott gesztusokra, a közös tevékenység reményére és a várható sikerre is vonatkozik. A tükörneuron-rendszer aktivitása a szemlélő számára érthetővé teszi az adott cselekvés célját [18], továbbá emulatív, előrevetítő, cselekvésrekonstruáló szerepú [19]. Következésképpen, testi és lelki funkcióink elválaszthatatlanok lévén, kölcsönösen befolyásolják egymást, és ezáltal a betegségek kialakulását és a beteg hozzáállásán keresztül a gyógyulás esélyeit. Ezért mondhatjuk, hogy az orvos-beteg találkozás legkisebb egysége maga a kapcsolat. Így beszélhetünk kapcsolatközpontú gyógyításról.

\section{A pszichoszomatika jelen állása: régi fogalmak, új tudományágak}

A pszichoszomatika az orvosi pszichológia oktatásának és múvelésének kitüntetett része. Nem csupán egy határterületi részdiszciplínáról van szó, hanem az orvostudomány igen fontos elméleti/szemléleti keretéról és gyakorlati vezérfonaláról (így tehát a fogalom kettős). A test és lélek határterületének tudományos megközelítését tartalmazza.

A pszichoszomatika - éppen határterületi voltánál fogva - különböző szemléletek és nézetek ütközésének terepévé is vált, a fogalmi bizonytalanságoknak köszönhetően. Európai fogalom, amely a klasszikus pszichoanalízisre épült. Ennek ellenpontjaként megjelent az Egyesült Államokban elterjedt magatartásorvoslás név is. Ezekkel részben átfedő területként fogható fel a stresszmedicina fogalma, amely a pszichoszomatikában szokványos jelenségek hátterében a kibóvített értelemben használt stresszt tartja központi elemnek. Meg kell említenünk a konzultációs-kapcsolati pszichiátriát is: ez a pszichoszo- matika gyakorlati oldalát, a szomatikus és pszichiátriai zavarok összefüggéseit jelenti.

A test és lélek együttes kezelésének igénye már az ókorban felmerült, emellett az antropológiából, a különböző kultúrákból sok példát ismerünk a gyógyítás egészleges (holisztikus) megközelítésére. A pszichoszomatika fogalma a XIX. század elején született, majd a XX. században, a pszichoanalízis kibontakozásával vett új lendületet. Ebben múlhatatlan érdemei vannak a magyar származású Franz Alexandernek, aki leírta a „hét szent betegség"-et: a pszichológiai háttér mindegyikükre különösen jellemző. Megjelent a pszichogenezis elmélete is, amely szerint a pszichoszomatikusnak tartott betegségeket specifikus pszichológiai tényezók okozzák - ez tehát a lineáris oksági modellen alapult.

A pszichoanalízis mellett a pszichoszomatika fejlődését a pszichofiziológia befolyásolta. Pavlov kondicionálási kísérletei az alapkutatások szintjén mutattak szoros összefüggést a pszichológiai tényezók és az élettani reakciók között. Ugyanígy Selye János stresszelmélete is lényeges hozzájárulásnak tekinthető. A pszichoszomatika lineáris okságot feltételező kezdeti teóriáit az 1970-es években zajló tudománytörténeti paradigmaváltás alapvetően megkérdőjelezte. A korábban egyeduralkodó, a descartes-i dualista filozófián nyugvó, a testet és a lelket élesen különválasztó, redukcionista, biomedikális modell helyett megjelent a biopszichoszociális betegségmodell, amelyben a többoldalú megközelítés és a cirkuláris okság játszik fontos szerepet. Ez alapvetően az általános rendszerelméletből fakadt, amely a tudományok számos területén megtermékenyítő hatású volt (ennek egyik következménye a rendszerbiológia megjelenése). E komplex modell az utóbbi évtizedekben kiegészült a spiritualitás dimenziójával: ez a létezés szellemi tartományát jelenti, az emberen túli magasabb értelem keresését a jelenségek mögött. Így a biopszichoszociális-spirituális betegségmodell számít a legmodernebbnek. Ez azt is jelenti, hogy a mai pszichoszomatikára az integratí megközelités jellemző.

A fent vázolt fejlődéstörténet mai állása az, hogy a pszichoszomatikát is elérte az utóbbi két-három évtizedben az élettudományokban tapasztalható robbanásszerú fejlődés. A pszichoszomatikának a szellemtudományokkal rokonított, néha naiv, néha vulgarizáló elképzelései helyett ma már igen erôs idegtudományi megalapozottságú elméletek igazolódtak, s ez eddig nem látott közeledést jelent a biológiai és a pszichoszociális tudományok között. Ez a tendencia - természetesen - terápiás oldalról is észlelhető: a terápiás kutatások erős területe lett az idegtudományi irány.

Érdemes röviden sorra vennünk azokat a modern tudományágakat, amelyek a pszichoszomatika mai, teljesen új értelmezéséhez vezettek.

A test és a lélek közötti kapcsolat már a klasszikus pszichofiziológiai kísérletekkel is jól igazolható. Ezek egyik igen fontos területe a zsigeri érzékelés. A homeosztázis fenntartását szolgáló motivációs viselkedésnek kognitív, affektív (érzelmi) és vegetatív oldala egyaránt van, így 
érthetô az érzelmek és az élettani múködések kapcsolata. A homeosztázis szabályozásában a szociális ingerek is részt vesznek. Meghatározóak lehetnek a közeli kapcsolatok (például az anya-gyermek kötódés) alakulásában. Az anya hiánya a csecsemőben számos élettani elváltozáshoz vezet (ezek alapján pszichoszomatikus tünetekhez, sốt személyiségzavarokhoz is). Ezek a kutatások több új tudományterületet nyitottak meg: kialakult a neuropszichoanalizis, a kapcsolati neurobiológia, a kötödéselméletek élettani vonatkozásainak kutatása. A neuropszichoanalízis összhangba hozza a klasszikus pszichoanalitikusi fogalmakat és az idegtudományokat. A korai kötődés (például az anya-gyermek kapcsolat) alapvetôen meghatározhatja az idegrendszer struktúráját is, ami többek között a stresszérzékenységben is nyomot hagy (1. ábra).

Pszichofiziológiai szempontból az exterocepció és az interocepció viszonya kitüntetett területe a test-lélek határkérdéseinek. Az, hogy a külvilág ingerei miként válnak testünk élettani mechanizmusokban tetten érhető részévé, az embodiment fogalmában mutatkozik meg. Bár sokan a „megtestesülés” szóval fordítják az embodimentet, más szót kell választanunk, mert a megtestesülés fogalma teológiai értelemben már foglalt. Talán a testbe ágyazottság kicsit nehézkes kifejezése lehetne alkalmas a lényeg megragadására. Az érzelmi és a kognitív folyamatok visceralis alapjairól van szó. Az interocepció közvetlen kapcsolatban áll a motivált cselekvésekkel, az érzelmekkel $[20,21]$. A zsigeri állapot folytonos monitorozása kiterjedt idegi hálózatokban reprezentálódik. Ennek az önszabályozásban kitüntetett jelentősége van. Egy példa: a hiányos belső percepció az önkontroll csökkenéséhez és testi túlerőltetéshez vezethet. Az önszabályozásban kiemelt szerepúek figyelmi és kognitív múködések is (jól ismert a szomatizáció esetében, hogy a fájdalomküszöböt a figyelmi fókusz csökkenti).

A pszichoneuroimmunológia az autoimmun, allergiás, gyulladásos, daganatos és fertőző kórképeknek a pszichológiai, az idegi és az immunfolyamatokkal való kölcsönhatásaival foglalkozik. Ehhez közeli a pszichoneuroendokrinológia, amely az endokrin rendszer ilyen vonatkozásait kutatja. A stresszelmélet központi eleme a hypothalamus-hypophysis-mellékvesekéreg tengely. A kutatások során a neurotranszmitterek, neuropeptidek, citokinek, hormonok fontos szerepére is rávilágítottak.

Új kutatási terület a pszichoterápiák biológiai hatásainak vizsgálata [22]. Azok a módszerek, amelyek hatását korábban kizárólag lelki mechanizmusokkal értelmeztük, különböző biológiai, idegtudományi paraméterekkel követhetők (például immunológiai vizsgálatokkal, képalkotó eljárásokkal). A pszichoterápia nemcsak a pszichofiziológiai mutatókat befolyásolja, hanem immunológiai válaszokat is okoz, befolyásolja a stressztengelyt és a génexpressziót. Fontos felhívni a figyelmet a tapasztalatfüggón neuroplaszticitásra, amely korábbi ismereteinkkel ellentétben azt jelenti, hogy a környezeti, például a tanult hatások meg tudják változtatni az idegrendszer struktúráját. Idegsejtek újdonképződése (neurogenezis) felnőttkorban is előfordul. Mindez azt jelenti, hogy a pszichoterápiás indikációk felállításában és a hatékonyság mérésében hamarosan biológiai, idegtudományi paraméterek is szerepet játszanak. E terület egyik érdekes leágazása a placebokutatás. A placebo hatásában a biológiai és pszichológiai tényezők, valamint a társadalmi-kulturális tényezők is fontosak.

Szintén új, mindössze két évtizedre visszanyúló kutatási területet jelentenek a szociális idegtudományok. Ezek a szociális viselkedésekben szerepet játszó biológiai-idegtudományi mechanizmusokat kutatják [12, 21, 23]. A tudományág fó területei ma:

- agyi képalkotó vizsgálatok normális gyermekekben és felnőttekben;

- a szociális viselkedések állatmodelljei;

- agyi vérkeringészavarban (stroke) szenvedő betegek vizsgálatai;

- pszichiátriai betegek vizsgálata agyi képalkotó eljárásokkal;

- a perifériás idegi, neuroendokrin és immunológiai folyamatok szociális meghatározóinak kutatása.

Az öröklés és tanulás viszonya a pszichológiai és a biológiai tudományokban egyaránt sokat elemzett terület. Ma ez alapvetően megváltozott a gének funkcionális folyamatait vizsgáló epigenetika jegyében. A neuroplaszticitás (lásd fentebb) erős epigenetikus befolyás alatt áll [24]. A genetikai kód expresszióját számos környezeti hatás képes megváltoztatni. A hagyományos genetika lineáris oksági modelljeit (a gének gyöngysorszerú szekvenciájának fontosságát) felváltotta a rendszergondolkodásban ismert többtényezős, komplex modellek világa. Szerepe van a korai élettapasztalatokon nyugvó stresszválasznak, a szociális tapasztalatoknak, a hőmérsékletnek, a táplálkozási tényezőknek, a sportnak és így tovább. Azok a tényezők tehát, amelyek korábban „puha” besorolást kaptak, ma már a biológiai kutatások evidenciáinak megfelelően „keménynek” tekinthetők. Így könnyebben magyarázhatók a korábban tisztán pszichológiainak látszó jelenségek (a pszichoterápiás hatások is).

A pszichoszomatika lényeges terepe a szociális történéseknek a testi állapotra gyakorolt hatása is. Ennek nyomán jelent meg a szocioszomatika fogalma. Az egészséget erősen befolyásolja a szocioökonómai státusz és az úgynevezett „társadalmi tőke” is (ez a társadalom önsegíto és tagjait támogató potenciálját jelenti). A társadalmi hatások és az egészségi állapot kapcsolatában a krónikus stressz és a depresszió kulcsszerepe említhető. Kiemelhetô az is, hogy a fájdalom percepciójában is lényegesek a társas hatások. A szomatikus fájdalom mellett a szociális fájdalmat is leírták: a szociális elutasítást vagy veszteséget gyakran fájdalomként írják le. Ennek biológiai alapja az, hogy a kétféle jelenség azonos neuronalis területeket érint [25]. Az említetteken túl számos olyan pszichológiai és szociális tényezó ismert, amely a betegségek iránti fogékonyságot módosítja (a korai és friss életeseményektől a krónikus stresszig és a stresszleküzdő mechanizmu- 
sokig, az életmódig és a társas támogatásig vagy különböző személyiségtényezőkig).

Túl a forradalmian új tudományos eredményeken, a pszichoszomatika gyakorlati oldala is igazolja a szemlélet létjogosultságát. Azoknak a zavaroknak az aránya, amelyekben a pszichoszociális tényezők alapvetőek, népegészségügyi méreteket öltött. Egy jól ismert példa a gasztroenterológia területéról: az irritábilisbél-szindróma prevalenciája 10-20\% körüli az átlagnépességben. Említhetjük az orvostudomány számos részterületét a bőrgyógyászattól a nőgyógyászatig, a fül-orr-gégészettől a gyermekgyógyászatig és így tovább. Az is lényeges, hogy jelentős a pszichiátriai komorbiditás a legkülönbözőbb testi betegségekben (leginkább a depresszió és a szorongásos zavarok). Ez a konzultációs-kapcsolati pszichiátria fontosságát húzza alá. E zavarokra a "jéghegyjelenség” érvényes: a betegek csupán kis hányada keres orvosi, még kevesebben pszichiátriai-pszichoterápiás segítséget (általában $5 \%$ a különböző, ilyen típusú zavarokban). Így a pszichoterápiák gyakorlati alkalmazásának szükségessége szembeötlő. Természetesen nem arról van szó, hogy lege artis pszichoterápiát kell folytatni sok szomatikus beteggel, de a pszichoterápiás szemlélet, az egyszerü gyakorlati intervenciók ismerete egészségügyi gazdaságossági szempontból is lényeges volna. A pszichoterápia jelentősége a következőkben ragadható meg [26]:

- növeli az adherenciát és a compliance-t;

- adekvát betegségtudatot és betegségpercepciót épít ki;

- csökkenti a pszichés tünetek betegségterheit (szorongás, tehetetlenség);

- csökkenti a betegségek fenntartásában részt vevő magatartásmintákat;

- megelőzi és kezeli a komorbid mentális zavarokat;

- javul a betegség lefolyása;

- javulnak a kísérő pszichés tünetek, zavarok;

- javul az életminőség.

\section{Alkalmazott egészségpszichológia}

A modern pszichoszomatikus - komplex biopszichoszociális - szemlélet jegyében végzett gyógyító munka integrált, multidiszciplináris teamekben zajlik. Ezekben a teamekben egyre több helyen pszichológus - klinikai vagy egészségpszichológus - is dolgozik. Az 1970-es évek óta a kezdetben klinikai pszichológiai alapokon fejlődő, majd önálló szemléleti keretekkel megerősödő egészségpszichológia diszciplínáján belül négy szakterület specializálódott: a nemzetközi nómenklatúrában klinikai egészségpszichológiának (clinicalhealthpsychology-hazánkban alkalmazott egészségpszichológiának) nevezett terület, továbbá a preventív, a közösségi és kritikai egészségpszichológia. A betegellátáshoz elsősorban az alkalmazott egészségpszichológia kapcsolódik. Magyarországon 2012 óta zajlik az Alkalmazott egészségpszichológiai szakpszichológus szakképzés (jelenleg a Szegedi Tudományegyetem az egyetlen szakképző hely), melynek elsődleges célja a szakemberképzés, a betegellátás és az egészségprevenció hatékonyságának növelése, a gyógyító szakemberek képzése, stresszkezelésük támogatása és kiégettségük megelőzése, továbbá a lakosság egészségi állapotának javítása. Amint az a szaktevékenység szabályozását tartalmazó 28/2017. (X. 25.) EMMI rendeletben is szerepel, az alkalmazott egészségpszichológiai intervenciók a betegellátásban és a prevencióban folyó gyakorlati munkára irányulnak. Az egészségpszichológia nem a pszichopatológiai modellekre épít, hanem az egészséges erőforrások mozgósítását állítja a középpontba. A krónikus vagy esetenként végzetes kimenetellel fenyegető betegségtől szenvedő személyek számára a betegség által kiváltott krízis, esetenként trauma, a szociális és individuális korlátozó tényezők életvezetést módosító hatásainak feloldásán keresztül teremti meg a beavatkozás feltételeit. Az egészségpszichológusok a klinikai pszichológusokkal és más szakemberekkel együttmúködő multidiszciplináris csoportok meghatározó tagjai.

Az alkalmazott egészség-szakpszichológusok elsődlegesen a szomatikus betegellátásban jelentkező pszichológiai problémák megoldásában segítik a hatékonyabb gyógyító munkát, mind az alap-, mind a szakellátásban. Támogatást és speciális kezelési programokat kínálnak az akut, krónikus és terminális betegségekben szenvedő páciensek számára, segítik a szakemberek és betegek kommunikációját, a kezelésekkel kapcsolatos hatékonyabb döntéshozatalt és együttmúködést. Segítenek a gyógyító szakembernek a munkahelyi stressz kezelésében és a kiégettség megelőzésében. Szakmai ismereteiket alkalmazhatják az elsődleges betegségmegelőzés területén is, a rizikóviselkedések prevenciója és az egészségfejlesztés céljából. Részt vesznek a gyógyító szakemberek orvosi pszichológiai és egészségpszichológiai tárgyainak oktatásában, az orvos- és egészségtudományi, illetve a pszichológusi alapképzésben.

Az alkalmazott egészségpszichológiai szakpszichológusok a szakmai protokoll szerint az alábbi feladatok ellátásában vesznek részt:

- a kompetenciakörbe tartozó problémák felismerése és szakszerú problémamegoldás (a megfelelő módszer kiválasztása, alkalmazása);

- az egyes betegségekhez, speciális kezelési helyzetekhez kapcsolódó pszichológiai problémák kezelése az alap- és szakellátásban (háziorvosokkal, szakorvosokkal, klinikai teamekkel együttmúködve);

- a betegségekkel való megküzdés technikáinak fejlesztése, segítségnyújtás a társas támogatás lehetőségeinek feltárásában, az egészségtudatos orientáció kialakításában;

- stresszkezelési és egészségfejlesztő technikák alkalmazása a gyógyító szakemberek, illetve a lakosság számára;

- kapcsolati, döntési és kommunikációs problémák megoldásának támogatása a betegellátás és a prevenció különböző szintjein;

- tanácsadás az egészséggel és betegséggel kapcsolatos ismeretek publikus kommunikációja terén (szóróanyagok, ismeretterjesztő kiadványok, médiaanyagok, tré- 
ningek, képzések tervezése, az egészségmúveltség fejlesztése);

- felmérések, kutatások végzése egészség- és betegségmagatartással, biopszichoszociális folyamatokkal kapcsolatban egészségügyi intézmények vagy szakemberek számára;

- egészségtudományi és pszichológiai szakemberképzésben való részvétel.

$\mathrm{Az}$ alkalmazott egészségpszichológiai kompetenciák fő jellemzője a betegségek kialakulásának és gyógyításának komplex, biopszichoszociális szemlélete és az erre épülő hatékony problémamegoldás, kezelési eljárások, egészséges erőforrások mobilizálása a gyógyulás és az egészségpromóció érdekében. További fontos jellemző a páciensközpontú és kapcsolatorientált, rendszerszemléletű látásmód az elsődleges, másodlagos és harmadlagos prevenció területén jelentkező individuális viselkedési jelenségekkel és társas helyzetekkel kapcsolatban [5].

Az alkalmazott egészség-szakpszichológusok egyre nagyobb számban vesznek részt az egészségügyi ellátásban. Az ország több egyetemi klinikáján, országos centrumokban, budapesti és vidéki kórházakban alkalmaznak egészségpszichológusokat az ellátásban a legkülönfélébb orvosi szakágakhoz kapcsolódóan. Egyre több ellátási területen, klinikán, fekvőbeteg-osztályon és ambulancián dolgozik már egészségpszichológus, de jelentős fejlesztést és szemléletformálást igényel még, hogy a pszichológusok alkalmazása széles körben elterjedhessen az ellátásban a legkülönbözőbb orvosi szakágakhoz kapcsolódóan. Az egészségpszichológusok komoly szerepet kapnak az alapellátásban is: részt vesznek a hazai háziorvosi rendszer fejlesztését, társszakmáival való kapcsolatának erősítését célzó Alapellátás-fejlesztési Modellprogramban.

\section{Az orvosi pszichológia, a pszichoszomatika és az egészségpszichológia oktatásának kihívásai}

A múlt század kilencvenes éveiben a magyar orvosképzésben is megjelentek az önálló magatartástudományi intézetek. Ezek feladata azon témaköröknek az oktatása, amelyek egyrészt hozzájárulnak a hivatásra neveléshez, másrészt azt a biopszichoszociális (mára kibővülve a spirituális dimenzióval) szemléletet közvetítik, amely lehetővé teszi, hogy a leendő orvosok betegeiket plasztikusan lássák, ezzel emelve gyógyító munkájuk hatékonyságát - egyúttal teljesítsék az orvosképzésnek a XXI. század tízes éveire jellemző vezető kívánalmát, miszerint legyen a képzés „etikai értékeken alapuló, páciensközpontú” [27]. Ha visszatekintünk az orvosképzés változó trendjeire, akkor párhuzamosan követhetjük az orvosi pszichológia, illetve a magatartástudományi tárgyak oktatásának változásait is. Az 1980-as években a „kognitív teóriák" uralták a képzést, és az aktív ismeretátadási konstrukciók domináltak a tanításban. Ekkor indult a pszichológiai ismeretek integrálása az orvosképzésbe, és erre az időszakra tehető az információs technológiák térhódítása is. A közösségi medicina kezdete, a népegészségügyi szükségletek középpontba állítása ezekre az évekre jellemző, valamint ekkor rajzolódik ki a mentális egészség fontosságának felismerése.

Az ezredfordulóra az orvosképzésben ismét új irányvonalak bontakoztak ki, amelyeket a „hivatásteóriák” névvel jelöltek. Ekkor már a betegközpontúságra, a kulturális kompetenciák oktatására helyezik a hangsúlyt. A társadalmi felelősség adja az alapját a kimenet típusú curriculumoknak, előtérbe kerül a kulturális diverzitás szempontja. Mindez a magatartás-tudományi tárgyak között szereplő orvosi antropológia pozíciójának megerősödését eredményezi. A globalizáció, az orvosképzés üzleti jellegének erősödése, valamint az információs technika fejlődése megköveteli a betegek és közösségek etikai biztonságának növelését. Ezek a tendenciák kedveznek a magatartástudományi tárgyak megerősödésének és a beteg személyiségére, méltóságára irányuló nagyobb figyelemnek. A fent vázolt oktatásfejlesztési vonulatba illeszkedik az orvosi pszichológia oktatása, a pszichoszomatikai és egészségpszichológiai kurzus bevezetésének igénye is. A hallgatók gyakorlati képességet fejlesztő kurzusokra vágynak, hiszen az elméleti anyag elérésére már az e-learning-módszerek is lehetőséget adnak. A saját készségek elemzésére alkalmasak a videotechnikák. Az orvosi pszichológia oktatása során, régen túllépve az előadás és szeminárium hagyományos metodikáján, a hallgatók változatos módszerekkel ismerkedhetnek meg. A filmes esetelemzés, szerepjáték, majd a szimulált, beteggel gyakorolt kommunikációs tréning, videoelemzés az orvosi pszichológia tanításának két évtized óta elidegeníthetetlen eszköztárába tartozik, ezzel is biztosítva a betegközpontú oktatás kívánalmának megvalósulását, valamint a hatékony készségfejlesztést. A számonkérés körében a tesztvizsga mellett ott vannak a strukturált esszékészítések, a szóbeli esetelemzések és a megfigyelési csekklisták is. A három féléven végigvonuló pszichológiatanulási folyamat elemzése a portfólió módszerének alkalmazásával végezhető [28].

Az európai orvosképzési irányok figyelembevételével, új kurzus indítása a pszichoszomatika témakörében adekvát választ jelent a klinikai igényekre, lehetőséget adva a holisztikus szemlélet megerősítésére is. Problémaorientált megközelítési módot alkalmazva, a hallgató nem diszciplináris széttöredezettségben, hanem a beteget teljes biopszichoszociális egységben látva ismeri fel a betegség patomechanizmusát, állítja fel a diagnózist, és ilyen szemléletben javasolja, alkalmazza a terápiás lépéseket [29]. A klinikai esettanulmányok megoldása során a tünetek mérséklésén túlmutatva veszik figyelembe a beteg személyiségét és pszichoszociális körülményeit. A cél az, hogy a hallgató a kurzus végére rendelkezzen integratív, holisztikus szemlélettel, legyen tisztában a leggyakoribb pszichoszomatikus betegségek pszichoneuroimmunológiai hátterével, lássa e betegségek komplexitását, 
tapasztalja meg a teammunka sajátosságait, abba bekapcsolódva legyen képes adekvát kérdések feltevésére.

Oktatási stratégiaként az interprofesszionális oktatás (IPO) választása tû́nik a leghatékonyabbnak. Abban az esetben beszélünk IPO-ról, ha két vagy több hivatás képviselője együttmúködve oktatja a hallgatókat. Kollaborációjuk a teammunka példája. A hallgatók számára saját tapasztalattá válik, hogy a közös cél érdekében együtt kell dolgoznia orvosnak, pszichológusnak, pszichiáternek. A kívánt kompetenciákat gyakran a különböző hivatások alakítják. Sokkal hatékonyabb, ha együtt biztosítják az ismeretek, készségek elsajátítását és az attitüd alakítását, ezt a hallgatók jobban magukévá teszik. Az integrált szemlélet eredményeként a különböző hivatások, ismeretrendszerek és pszichoszociális szempontok elfogadtatása is könnyebbé válik ezzel [30-33]. Problémaorientált módszert alkalmazva, az adott klinikumban előforduló pszichoszomatikus betegségek expozícióját követi az esetbemutatás, integrált megközelítéssel. A szakemberek együtt készítik elő a kazuisztikát, majd ott, a foglalkozás keretében modellezik két szakember konzultációját. A hallgatók számára lehetőség nyílik az aktív részvételre, kérdéseik megfogalmazására és a betegtől való kérdezésre. Megismerik a beteg személy komplex megközelítését, a betegközpontú kezelési lehetőségeket, az irányelveket. A klinikai blokk legnagyobb értékét mindig az aktuálisan bemutatott beteg jelenti, a szakemberek hozzá intézett kérdései alapján áll össze a plasztikus kép, válik a hallgatók számára nyilvánvalóvá a test és lélek elválaszthatatlansága.

Az orvosi pszichológia, a pszichoszomatika fejlődése folyamatos kihívást jelent az oktatásban. Ez újabb és újabb fejlesztést igényel, a graduális és a szakorvosképzésben egyaránt. Ahogyan Michelle McLean [34] mondja: „az oktatásfejlesztés nem luxus, hanem kötelesség minden orvosképző hely számára”.

\section{Következtetés}

Az orvosi tevékenység jelentősebb pszichológiai mozzanatait felsoroló írásunk a terápia hatékonyságát garantáló orvos-beteg kapcsolat biopszichoszociális összetevőit és oktatásfejlesztési lehetőségeit mutatta be. Az emberi jogok tisztelete - a kollégákkal és a betegekkel való kapcsolat szabályozásán keresztül - a fizikai adottságoktól részben függetlenül is megalapozza a gyógyítás eredményességét. A betegellátás során két szakértő - az orvos és a beteg - különböző ismeretek és tapasztalatok birtokában van, de céljuk közös: az egészség megtartása vagy visszaszerzése. A gyógyulás tehát közös erófeszítés eredménye, amelynek alapja a kölcsönös bizalom, tisztelet és megbecsülés, és amely a beteg állapotától függően járul hozzá a várt gyógyulás eléréséhez. Az eredmény annál meggyőzőbb, minél több erőforrást tud az orvos a beteg ismereteiből, személyes fizikai, lélektani és társas lehetőségeiből mozgósítani. A betegek által is elvárt további feladatai közé tartozik, hogy az egészségügyi ellátórend- szer kínálta lehetőségekből a betegei érdekében minél több forráshoz hozzá tudjon jutni, valamint innovációkkal önmaga is bővítse az egészségügy repertoárját. Az orvos a gyógyító kapcsolat kialakítására való képességével jelentősen növeli a beteg gyógyulási esélyeit. Az orvos teremti meg azt a közeget, amelyben a testi, lelki, szociális és spirituális hatások az egészség megőrzése vagy helyreállítása érdekében összekapcsolódnak egymással. Manageri képességeit fejlesztve megalkotja és fenntartja, beosztottjai számára is biztosítja a megfelelő gyógyító közeget, továbbá gondoskodik a betegekkel való megfelelő gyógyító kapcsolat fenntartásáról. A források és a megfelelő munkatársak rendelkezésre állása, a személyzet rekreációjának hiányosságai [35], az időprés és a szakmai fejlődést korlátozó tényezők fékezik a betegközpontú ellátást. Következésképpen nő a betegek ellátással kapcsolatos elégedetlensége, csökken adherenciájuk mértéke és ezzel párhuzamosan a gyógyítás eredményessége is. Az orvosi pszichológia megközelítése szerint az orvos feladataihoz nemcsak a beteggel való közvetlen gyógyító kapcsolat fenntartása, de a gyógyító közeg kiépítése is hozzátartozik. Az orvos a feladatait megosztja, de a felelösséget nem. A betegnek tudnia kell, ki az ő orvosa, akinek a kezében összefut minden információ, akivel megbeszélheti kérdéseit, akinek elmondhatja aggodalmait és megfogalmazhatja álláspontját. Az orvos arra törekszik, hogy a munkacsoportja számára rendelkezésre álló és folyamatosan fejlesztett erőforrásokat hatékonyan használja és ossza fel munkatársai között. Szakértelmét és az általa múködtetett egészségügyi hálózatot a betegek megkülönböztetése nélkül használja fel. A beteget tájékoztatja és bevonja a kezeléssel kapcsolatos döntésekbe, megosztja vele a kezelés sikeréhez szükséges információkat. Ellenszolgáltatásként csak a beteg együttmúködését várja el. A beteg hozzátartozóit az ellátásban és a rehabilitációban egyaránt segítő munkatársnak tekinti: rajtuk is múlik a beavatkozás eredményessége. A nem kielégítő tudatállapotú betegek hozzátartozóit és/vagy jogi képviselőit - a lehetőségeket figyelembe véve - mihamarabb bevonja a beteggel kapcsolatos döntésekbe. A beteg biopszichoszociális és spirituális rendszerben való gyógyítása nemcsak a beteg személyes egészségi állapotát, de családja, társas környezete egészségállapotát is befolyásolja (és viszont). Az orvosi hivatásból származó gyógyító motiváció és hatékonyság így a társadalom és a kultúra fejlődéséhez való közvetlen hozzájárulás is egyben.

Anyagi támogatás: A közlemény elkészítése anyagi támogatásban nem részesült.

Szerzői munkamegosztás: K. J., B. K., T. F., Cs. M., M. P. azonos mértékben járult hozzá az összefoglaló írás elkészítéséhez. A cikk végleges változatát valamennyi szerző elolvasta és jóváhagyta.

Érdekeltségek: A szerzőknek nincsenek érdekeltségeik. 


\section{Irodalom}

[1] Andorka R, Pataki F. (eds.) Social adaptation disorders in Hungary I-II. [Társadalmi beilleszkedési zavarok Magyarországon I-II.] MTA, Budapest, 1984. [Hungarian]

[2] Kopp M, Kovács ME. (eds.) Quality of life in Hungarian population at turn of the millennium. [A magyar népesség életminősége az ezredfordulón.] Semmelweis Kiadó, Budapest, 2006. [Hungarian]

[3] Kopp M, Berghammer R. (eds.) Medical psychology. [Orvosi pszichológia.] Medicina Könyvkiadó, Budapest, 2005. [Hungarian]

[4] Csörsz I, Molnár P, Csabai M. Medical students on the stage: an experimental performative method for the development of relational skills. Med Teach. 2011; 33: e489-e494.

[5] Csabai M, Molnár P. Medical psychology and applied health psychology. [Orvosi pszichológia és klinikai egészségpszichológia.] Medicina Könyvkiadó, Budapest, 2009. [Hungarian]

[6] Antal-Uram D, Harsányi L, Perczel-Forintos D. Low-intensity, evidence-based cognitive-behavioural therapy of a patient with Crohn's disease. [Az alacsony intenzitású, bizonyítottan hatékony kognitív viselkedésterápia Crohn-betegségben.] Orv Hetil. 2018; 159: 363-369. [Hungarian]

[7] Hegedûs K. Polemics about the concept of good death. [Létezik-e jó halál?] Oriold Kiadó, Budapest, 2017. [Hungarian]

[8] Pócs D, Hamvai Cs, Kelemen O. Health behaviour change: motivational interviewing. [Magatartás-változtatás az egészségügyben: a motivációs interjú.] Orv Hetil. 2017; 158: 1331-1337. [Hungarian]

[9] Decety J, Skelly L. The neural underpinnings of the experience of empathy: Lessons for psychopathy. In: Ochsner KN, Kosslyn SM. (eds.) Oxford Handbook of Cognitive Neuroscience - Volume 2. Oxford University Press, New York, NY, 2013; pp. 228243.

[10] Nagy E, Molnár P. Homo imitans or homo provocans? Human imprinting model of neonatal imitation. Infant Behav Development 2004; 27: 54-63.

[11] Kállai J. Neuropsychology of social relationships. [Társas kapcsolatok neuropszichológiája.] Medicina Könyvkiadó, Budapest, 2013. [Hungarian]

[12] Panksepp, J. Affective neuroscience. The foundations of human and animal emotions. Oxford University Press, New York, NY, 1998.

[13] Buda B. Psychological concept of empathy. [Empátia - A beleélés lélektana.] L’Harmattan Kiadó, Budapest, 2012. [Hungarian]

[14] Rizzolatti G, Fogassi L, Gallese V. Neurophysiological mechanisms underlying the understanding and imitation of action. Nat Rev Neurosci. 2001; 2: 661-670.

[15] Fodor JA. A theory of the child's theory of mind. Cognition 1994; 44: 283-296.

[16] Guastella AJ, Mitchell PB, Dadds MR. Oxytocin increases gaze to the eye region of human faces. Biol Psychiatry 2008; 63: 3-5.

[17] Buchheim A, Heinrichs M, George C, et al. Oxytocin enhances the experience of attachment security. Psychoneuroendocrinology 2009; 34: 1417-1422.

[18] Fogassi L, Ferrari PF, Gesierich B, et al. Parietal lobe: from action organization to intention understanding. Science 2005; 308: 662-667.

[19] Csibra G. Action mirroring and action understanding: An alternative account. In: Haggard P, Rosetti Y, Kawato M. (eds.) Sensorimotor foundations of higher cognition. Attention and performance XXII. Oxford University Press, Oxford, 2007; pp. $435-459$.
[20] Herbert BM, Pollatos O. The body in the mind: on the relation ship between interoception and embodiment. Top Cogn Sci. 2012; 4: 692-704.

[21] Horváth L, Szabó A. Mirror neurons and interpersonality in the paradigm of embodied mind. [Tükörneuronok és személyköziség a megtestesülés paradigmájában.] Lege Artis Med. 2013; 23: 629-634. [Hungarian]

[22] Singer T. The past, present and future of social neuroscience: a European perspective. Neuroimage 2012; 61: 437-449.

[23] Polgár P, Réthelyi J, Unoka Zs. The psychotherapy effect to biological processes. In: Unoka Zs, Purebl Gy, Túry F, et al. (eds.) The basis of psychotherapy. [A pszichoterápia biológiai hatásai. In: Unoka Zs, Purebl Gy, Túry F, et al. (szerk.) A pszichoterápia alapjai.] Semmelweis Kiadó, Budapest, 2012; pp. 49-57. [Hungarian]

[24] Hatala AR. The status of the "biopsychosocial" model in health psychology: towards an integrated approach and a critique of cultural conceptions. Open J Med Psychol. 2012; 1: 51-62.

[25] Eisenberger NI. The neural bases of social pain: evidence for shared representations with physical pain. Psychosom Med. 2012; 74: 126-135.

[26] Túry F, Purebl Gy. Basic concepts in psychosomatics. In: Füredi J, Németh A. (eds.) Hungarian handbook of psychiatry. [In: Füredi J, Németh A. (szerk.) A pszichoszomatika fogalma.] [A pszichiátria magyar kézikönyve.] Medicina Könyvkiadó, Budapest, 2015; pp. 758-767. [Hungarian]

[27] Hutchinson TA. Whole person care: A new paradigm for the 21 st century. Springer Verlag, Berlin, 2011.

[28] Harden RM. Learning outcomes and instructional objectives: is there a difference? Med Teach. 2002; 24: 151-155.

[29] Janssen-Noordman AM, Merriënboer JJ, van der Vleuten CP, et al. Design of integrated practice for learning professional competences. Med Teach. 2006; 28: 447-452.

[30] Barabás K. Unifying medical education: challenges of the 21 st century. In: Tarkó K. (ed.) The science of health enhancement. [Egységesülő orvosképzés, a XXI. század kihívásai.] In: Tarkó K. (szerk.) Egészségfejlesztés a tudományokban. Szemelvények a Szegedi Egészségfejlesztő Műhely hazai és nemzetközi tudományos munkáiból.] Szegedi Egyetemi Kiadó, Szeged, 2008; pp. 153-159. [Hungarian]

[31] Harden RM. AMEE guide No. 12: Multiprofessional education: Part 1 - Effective multiprofessional education: a three-dimensional perspective. Med Teach. 1998; 20: 402-408.

[32] Genn JM. AMEE Medical Education Guide No. 23 (Part 1): Curriculum, environment, climate, quality and change in medical education - a unifying perspective. Med Teach. 2001; 23: 337-344.

[33] Vértes A, Szabados E. Cardiovascular prevention - 2016. [Cardiovascularis prevenció - 2016.] Orv Hetil. 2016; 157: 15261531. [Hungarian]

[34] McLean M, Cilliers F, Van Wyk JM. Faculty development: yesterday, today and tomorrow. Med Teach. 2008; 30: 555-584.

[35] Németh A. Burnout among doctors and its correlations with health, life satisfaction and sleep. [Orvosok kiégettségének összefüggése az egészséggel, életérzéssel, alváskörülményekkel.] Orv Hetil. 2016; 157: 623-630. [Hungarian]

(Kállai János dr., Pécs, Szigeti út 12., 7624 e-mail: janos.kallai@aok.pte.hu) feltéve, hogy az eredeti szerzỏ és a közlés helye, illetve a CC License linkje és az esetlegesen végrehajtott módositások feltüntetésre kerülnek. 